\title{
¿Debemos tratar la bacteriuria asintomática en mujeres mayores?
}

\section{Caso clínico}

La Sra. S de 70 años de edad tiene antecedentes de hipertensión arterial. Consulta para realizar un control y el médico tratante le solicita una orina completa entre otros análisis a fin de determinar la presencia o no de proteinuria. La Sra. S está asintomática. El análisis de orina es normal excepto por la presencia de 7 leucocitos por campo. El médico solicita un urocultivo que resulta positivo (más de 100.000 colonias por $\mathrm{ml}$ ) de Escherichia coli resistente sólo a ampicilina. En el momento duda si debe o no tratar a la paciente, pero cree haber leído que la bacteriuria asintomática en mujeres mayores aumenta la morbimortalidad y decide indicar 7 días de co-trimoxazol. El médico comenta el caso con un colega que cree que la paciente no debió ser tratada. Deciden realizar una búsqueda que aclare la cuestión.

\section{Preguntas que generó el caso:}

1) ¿La presencia de bacteriuria asintomática es un predictor de mayor morbimortalidad en mujeres mayores?

2) ¿El tratamiento antibiótico de la bacteriuria asintomática, reduciría la morbimortalidad en estas mujeres?

Debe recordarse que la arquitectura de las preguntas a fin de que puedan contestarse a través de una búsqueda en MEDLINE debe contemplar la población (mujeres mayores), la intervención o la exposición a cierto factor de riesgo (tratamiento antibiótico/ bacteriuria asintomática) y el resultado (aumento o disminución de la morbimortalidad).

\section{Búsqueda en MEDLINE (sólo disponible en inglés)}

Se emplearon como palabras "clave" bacteriuria, rastreo, tratamiento fármacológico y morbimortalidad. Se "acotó" la búsqueda a mujeres mayores de 65 años y a estudios de cohorte (permiten ver asociación de un determinado factor de riesgo, en este caso la bacteriuria asintomática, con algún evento final, en este caso morbimortalidad) y a estudios randomizados (para evaluar tratamiento con antibióticos).

\section{Bacteriuria asintomática:}

Al definir bacteriuria asintomática debemos ser estrictos. Se debe constatar la presencia de 100.000 colonias por $\mathrm{ml}$ en una muestra de orina recolectada correctamente (chorro medio, higiene correcta de genitales). Si el urocultivo constata 100.000 o más colonias/ml, la probabilidad de infección es de $100 \%$ en hombres y $80 \%$ en mujeres. Dos cultivos positivos elevan la probabilidad de infección en mujeres al $95 \%$.

La prevalencia de la bacteriuria asintomática depende de la edad y el sexo. Entre los neonatos, se detectan urocultivos positivos en el $1 \%$ de los varones y de las mujeres. En la edad escolar, la prevalencia entre los varones es del $0.03 \%$ y del $1 \%$ en las nenas. Durante la época fértil, la prevalencia en mujeres es del 2 al $4 \%$ y hacia los 50 años alcanza el 5 al 10\%. Luego de los 65 años, hombres y mujeres tienen prevalencias parecidas debido a la presencia de enfermedades prostáticas y otras enfermedades urológicas que suelen requerir instrumentación en los pacientes de sexo masculino. La prevalencia de bacteriuria asintomática en este gruop etario supera el $15 \%$.

La mayor susceptibilidad de las mujeres jóvenes está explicada por la menor longitud de la uretra con el consiguiente acceso de gérmenes a la vejiga.

La prevalencia de bacteriuria es mayor aún en mujeres diabéticas con un riesgo relativo con relación a las no diabéticas de 3.

La importancia de la bacteriuria crónica o recurrente en la etiología de la insuficiencia renal crónica ha sido desestimada. Es más probable que los pacientes con bacteriuria sean hipertensos y que tengan anomalías estructurales en el tracto urinario. Raramente la insuficiencia renal crónica aparece como complicación de la bacteriuria en ausencia de anormalidades estructurales. La evidencia pareciera indicar que las anormalidades estructurales predisponen tanto a la bacteriuria como a la insuficiencia renal crónica.

Otra situación que preocupa a los médicos es la posibilidad de bacteriemia a punto de partida de la infección asintomática. Este riesgo es particularmente elevado en hombres con enfermedades prostáticas que requieren instrumentación. Se ha documentado bacteriemia en el $50 \%$ de hombres con orina infectada en el momento del procedimiento. Este riesgo es despreciable si la orina es estéril.

Un capítulo aparte se merecen las embarazadas con bacteriuria asintomá- tica. Estas mujeres sin tratamiento tienen el doble de riesgo de tener bebés de bajo peso con un riesgo relativo de mortalidad perinatal de 1.6. Estudios randomizados en mujeres embarazadas demostraron que el tratamiento antibiótico reduce tanto el riesgo de pielonefritis como de bebés de bajo peso.

La bacteriuria, que constituye un problema común en los adultos mayores, ha sido asociada con aumento de la mortalidad si t. i i la evidencia es controvertida. Si esto fuera asi, (la bacteriuria como fa. de riesgo independiente de mortalidad, y si se mostrara que su en an ación disminuyera el riesgo de muerte), debería propiciarse el rastr... tratamiento universal de bacteriuria en las mujeres mayores.

Veamos el resultado de nuestra búsqueda para tratar de resolver este punto.

\section{Resumen de los trabajos encontrados:}

1) Nicolle LE, Mayhew MJ, Bryan L: Prospective randomized comparison of therapy and no therapy for asymptomatic bacteriuria in institutionalized eldery women. Am J Med 1987;83:27-33. Este estudio se realizó en 50 mujeres (edad promedio 83.4 años) institucionalizadas con bacteriuria asintomática (más de 100.000 colonias en dos muestras). Se las randomizó a recibir tratamiento para todos los episodios identificados o sólo recibirlo si desarrollaban síntomas. Se realizó seguimiento de un año. El grupo tratamiento tuvo más reinfecciones (otro germen) ( 1.67 vs 0.87 por paciente-año) y más efectos adversos ( 0.51 vs 0.046 por paciente-año) que el grupo no tratamiento. No se encontró mayor morbilidad ni mortalidad entre grupos. En el grupo tratamiento sólo se logró que el $24 \%$ de las pacientes tuviera 6 meses o más de orina estéril. El estudio concluye que no se recomienda el tratamiento de la bacteriuria asintomática en ancianas. Estas conclusiones no deberian extrapolarse a población ambulatoria dado que se realizó con mujeres institucionalizadas.

2) Abrutyn E, Mossey J, Berlin JA, y cols: Does asymptomatic bacteriuria predict mortality and does antimicrobial treatment reduce mortality in eldery ambulatory women? Ann Intern Med 1994;120:827-33. Este es un estudio de cohorte y un estudio randomizado para el efecto del tratamiento. Se realizó en mujeres ambulatorias con una edad promedio de 81 años. El seguimiento fue a 3 años. Se realizaron cultivos cada 6 meses y se evaluó morbilidad y mortalidad. En el estudio observacional, las mujeres infectadas $(n=318)$ eran mayores y más enfermas que las no infectadas $(n=1173)$. A pesar de que en al análisis inicial tenían mayor mortalidad que las no infectadas (18.7 vs. 10.1 por 100.000 personas/día, $p<0.01$ ), en el análisis multivariado, la infección no estuvo asociada a un exceso de mortalidad (RR $1.1 ; p>0.2$ ). La edad al ingreso y una auto-evaluación del estado de salud si demostraron ser excelentes predictores de mortalidad. En el estudio randomizado, la mortalidad entre el grupo tratamiento y el controt no fue diferente RR 0.92 (IC $95 \% 0.57$ a 1.47). El estudio concluye que la bacteriuria no es un factor de riesgo independiente para mortalidad y que su tratamiento no hace disminuir la mortalidad. El rastreo y tratamiento de la bacteriuria asintomática en mujeres mayores para disminuir la mortalidad no parecen estar justificados.

\section{Conclusiones}

Los estudios que asociaron bacteriuria asintomática y mortalidad en adultos mayores han sido criticados por problemas metodológicos. En el estudio del Abrutyn y col. se observa que las mujeres con bacteriuria eran mayores y más enfermas. El análisis multivariado no pudo sostener la asociación entre bacteriuria y mortalidad. Ambos estudios comentados no pudieron demostrar diferencias en la mortalidad entre el grupo tratado y el no tratado.

Por lo tanto, a la luz de la evidencia publicada, las recomendaciones con relación a la búsqueda sistemática y tratamiento de la bacteriuria asintomática son: El rastreo de bacteriuria asintomática debe realizarse en población seleccionada de alto riesgo que incluye: a) mujeres embarazadas (el tratamiento reduce el riesgo de pielonefritis y bebés de bajo peso), b) hombres mayores antes y después de instrumentación urológica (alto riesgo de bacteriemia si la orina tiene gérmenes que se reduce dramáticamente si la orina es estéril), c) todo paciente cateterizado recientemente y d) paciente: con cálculos renales u otra anormalía urológica conocida. Dra. Karin Kopitowshi
pital Italiano de Buenos Aires 